\title{
FIRE RESISTANCE OF ALUMINIUM GLAZED CURTAIN WALLS Test results comparison depending on the side of fire exposure
}

\author{
Paweł Sulik, Jacek Kinowski, Bartłomiej Sędłak \\ Building Research Institute, Fire Research Department, Ksawerów 21 St., 02-656 Warsaw, Poland
}

\begin{abstract}
This paper discusses the main issues related to the fire resistance of aluminium glazed curtain walls including the tests methodology and way of classification of this type of building elements. Moreover, the paper presents the comparison of fire resistance test results of large test specimens of curtain walls in full configuration depending on the side of fire exposure. Temperature rises have been compared on unexposed surface of the curtain walls tested for standard and external fire exposure. To made the comparison four test specimens of glazed aluminium curtain walls in full configuration, were tested. Curtain walls had the same transom - mullion structure. Two test specimens were tested for external fire exposure, and two for standard fire exposure. Dimensions of exposed surfaces were $5000 \times 4500 \mathrm{~mm}$ (width $\mathrm{x}$ height) for external fire exposure and $5000 \times 4800$ $\mathrm{mm}$ (width $\mathrm{x}$ height) for internal fire exposure.
\end{abstract}

Keywords: curtain wall, fire resistance, integrity, insulation, aluminium profiles

\section{INTRODUCTION}

Curtain wall is a type of wall which usually consists of vertical and horizontal structural members, connected together and fixed to the floor supporting structure of the building to form a lightweight space enclosing continuous skin, which provides, by itself or in conjunction with the building construction all the normal functions of the external wall but doesn't take on any of the load bearing characteristics of the building. According to the regulations of many European Union countries in case of buildings for a specific purpose, (e.g. schools, hospitals, hotels) or buildings with significant height (Sulik et al., 2014) curtain walls as a non-load bearing elements of building should be designed and constructed in such a way that in case of fire it will limit the spread of fire inside the building and outside (to the adjacent buildings), allow the evacuation of users and ensure the safety of rescue team.

The above specified detailed requirements are not usually considered individually (e.g. ensuring proper evacuation is connected with the structural load bearing capacity, fire and smoke propagation within the building, and rescue team safety), therefore individual elements of buildings can play several roles during a fire.

This also refers to the building elements such as curtain walls which are usually required in terms of design and execution to ensure that in case of fire they shall for a specific period of time prevent its development between the adjacent floors of the building and between the adjacent objects. Moreover the fixing of the curtain walls shall be made in a way that prevents falling of the parts of element during the evacuation and rescue team activities (Kinowski et al., 2014; Kinowski 2015; Sulik et al., 2015).

\section{TECHNICAL SOLUTIONS}

Aluminium glazed curtain walls with a specific fire resistance class are usually made as mullion transom structures in which the areas between the aluminium profiles are filled with special fire resistant glass panes. The loadbearing members of the structure are mullions, typically in the form of aluminium profiles with box section (commonly with additional reinforcement made of steel or aluminium stiffening profiles). In order to improve thermal insulation, the profiles are also filled with special insulating inserts. Material of the inserts as well as the filling volume is dependent on 
the destination to use for the specific class of fire resistance of the curtain wall. The materials used for insulation inserts are usually gypsum plasterboards, silicate - cement or silicate calcium.(Kinowski et al.,2015)

The glazing as well as solution of profile insulation is selected depending on the expected fire resistance class of the curtain wall. The most commonly used in practice are glass units comprising a fireproof glass (toughened glass panes divided by the special gel or foil expanding under the influence of high temperature) coupled with the outer glass pane. Glass units are usually fixed in the curtain wall by means of pressure plates screwed to the main aluminium profile. Appropriate fixing of the glazing has a key role especially in the case of increasingly common glass units of large dimensions (Sędtak, 2014).

Important elements in the profile structure are intumescent gaskets placed on the perimeter of the glass panes. Intumescent gaskets expands under the influence of high temperatures and close the spaces through which the fire could get to the other side of the partition.(Sedtak et al., 2014)

Example profile cross-section is presented in fig. 1.

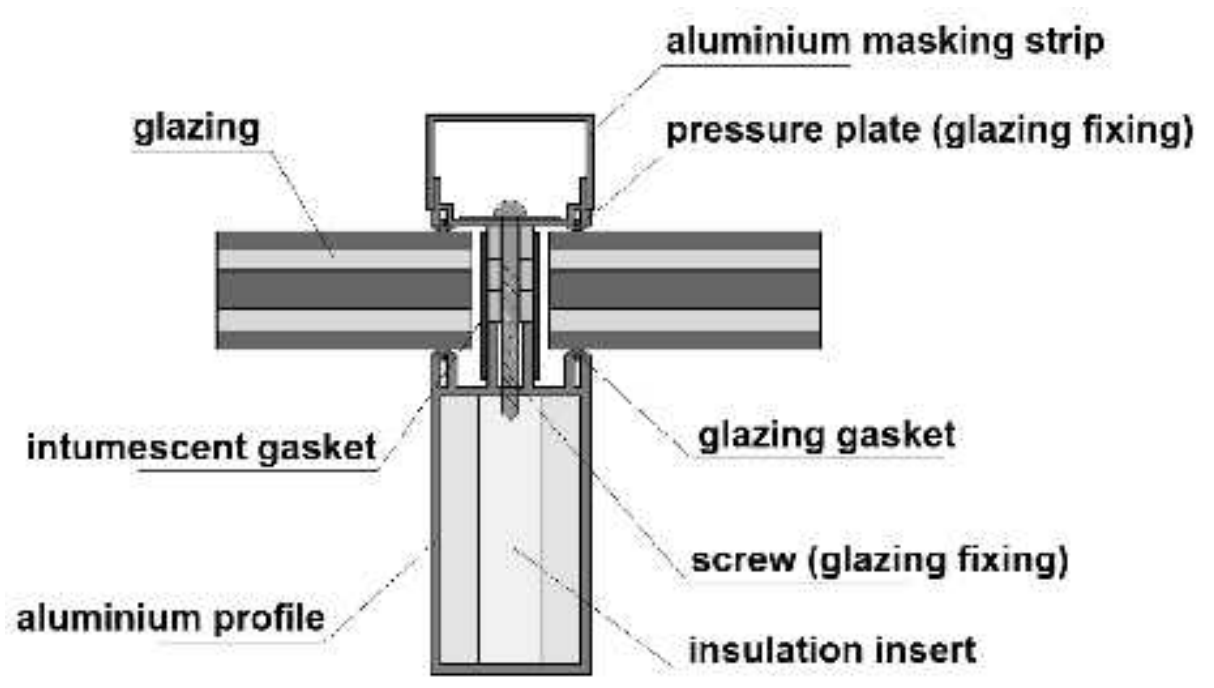

Fig. 1 Example profile cross-section (Sulik et al., 2014)

It is worth mentioning that solutions of this type are also used for roofing (Roszkowski et al., 2011; Roszkowski et al., 2014) - glazed roofs are made of exactly the same profile as those used in curtain walls.

\section{FIRE RESISTANCE TESTS AND CLASSIFICATION}

According to the European Union provisions the fire resistance test of glazed curtain wall in full configuration shall be performed in accordance with EN 1364-3:2014. The standard presents two different methods of heating and test specimen configuration depending on the side of fire exposure (external or internal). In case of internal fire exposure heating of the test specimen is held by the standard temperature-time curve, presented by the solid line in fig. 2, which is taken as an appropriate to reflect the fully developed, following the flashover fire inside the building. For external fire exposure heating of the test specimen can be held by external temperature-time curve, presented by the dashed line in fig. 2, which reflects the fire outside the building. The testing structure for the internal test shall comply of testing specimen and supporting construction made of two floor slabs and two associated wall constructions. For external fire exposure the testing structure is composed only of the test specimen and testing frame (optionally). (Sedtak, 2014)

The specimen for the test shall be fully representative of the curtain wall intended for use in practice (including any surface finishes and fittings which are essential and may influence its behavior in the test) or be designed to obtain the widest applicability of the test result to other similar constructions. (Sedtak, 2012) 


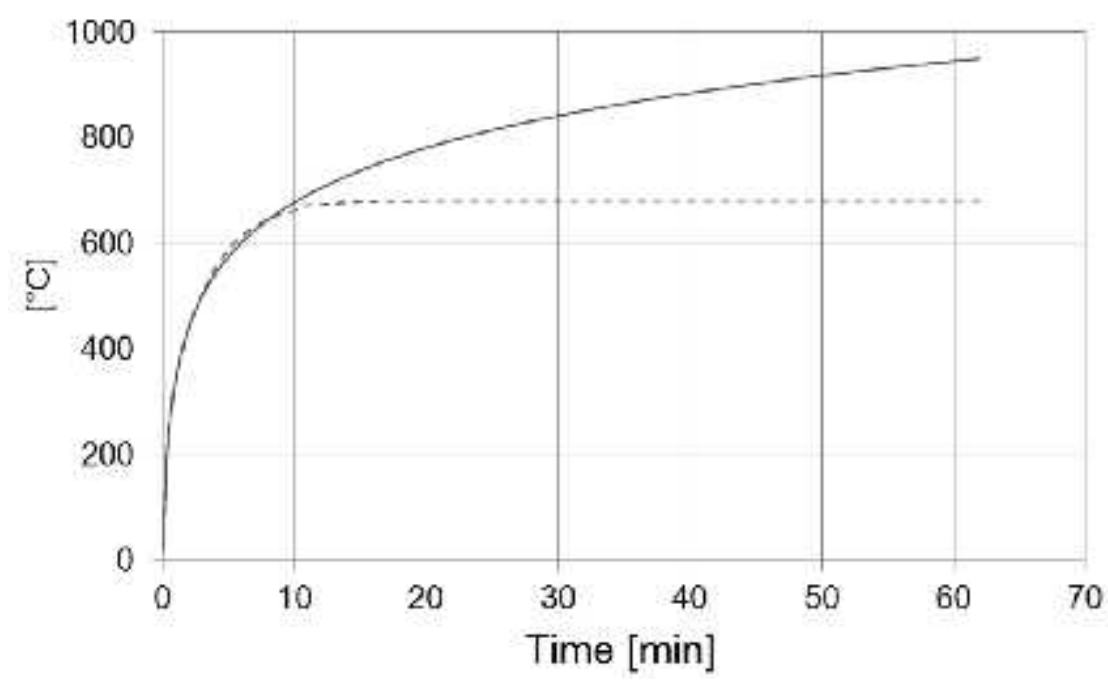

Fig. 2 Temperature-time curves, solid line - standard curve, dashed line - external fire curve (Sęltak, 2014)

During the fire resistance test performance criteria of integrity, insulation and radiation can be verified.

Integrity is the ability of glazed curtain wall to prevent the passage through it of flames and hot gases and to prevent the occurrence of flames on the unexposed side. In the test integrity is verified by means of cotton pad used on the unexposed surface of tested specimen, for max. of $30 \mathrm{~s}$, or until ignition; gap gauges (integrity fails if the $6 \mathrm{~mm}$ gap gauge can be passed through the crack in curtain wall and can be moved a distance of $150 \mathrm{~mm}$ along the gap, or if the $25 \mathrm{~mm}$ gap gauge can be passed through the crack in the specimen such that it projects into the furnace) and visually (integrity fails when flaming longer than $10 \mathrm{~s}$ occurs on the unexposed surface of curtain wall).

Insulation is the ability of test specimen to restrict the temperature rise of the unexposed face to below specified levels. The temperature rise on the unexposed surface of tested specimen is checked with thermocouples attached with use of heat resistant adhesive. Thermocouples are attached in the specific places given in the testing standard. In case of curtain walls, in order to maintain its insulation - maximum temperature rise cannot be greater than $180 \mathrm{~K}$ and average temperature rise cannot be greater than $140 \mathrm{~K}$.

Radiation is the ability of a test specimen to prevent the passage of the fire, due to the transfer of significant heat through the element to the adjacent materials. Radiation in the test is measured with the radiometer placed in the $1 \mathrm{~m}$ distance from the geometric center of the unexposed surface of heated part of curtain wall. Radiation is evaluated on the basis of the time at which the maximum radiation measured does not exceed $15 \mathrm{~kW} / \mathrm{m}^{2}$.

Classification of aluminium glazed curtain wall fire resistance is prepared in accordance with the requirements given in EN 13501-2:2009, basing on the test results presented in test report. Classification standard defines fire resistance classes presented in table 1.

Table 1 Fire resistance classes (Sędtak, 2012)

\begin{tabular}{|c|c|c|c|c|c|c|}
\hline $\mathrm{E}$ & 15 & & 30 & 60 & 90 & 120 \\
\hline $\mathrm{EI}$ & 15 & & 30 & 60 & 90 & 120 \\
\hline $\mathrm{EW}$ & \multicolumn{7}{|c|}{20} & 30 & 60 & & \\
\hline \multicolumn{6}{c}{ (E) - integrity, I Insulation, $\mathbf{W}$-radiation $)$} \\
\hline
\end{tabular}

Moreover each fire resistance class shall be supplemented by additional marking defining the side of fire exposure in the test.

\section{COMPARISON OF LARGE CURTAIN WALLS TEST RESULTS}

Four test specimens of glazed aluminium curtain walls in full configuration, were tested in Fire Testing Laboratory of Building Research Institute in Pionki. Curtain walls had the same transom - 
mullion structure. Two test specimens were tested for external fire exposure, and two for standard fire exposure. Dimensions of exposed surfaces were 5000 x $4500 \mathrm{~mm}$ (width x height) for external fire exposure and $5000 \times 4800 \mathrm{~mm}$ (width x height) for internal fire exposure. All tested specimens were of the same transom - mullion structure with aluminium profiles sections of $50 \times 115 \mathrm{~mm}$ (transoms) and $50 \times 130 \mathrm{~mm}$ (mullions). Figure 3 presents the structure of the test specimen for the internal fire exposure test.

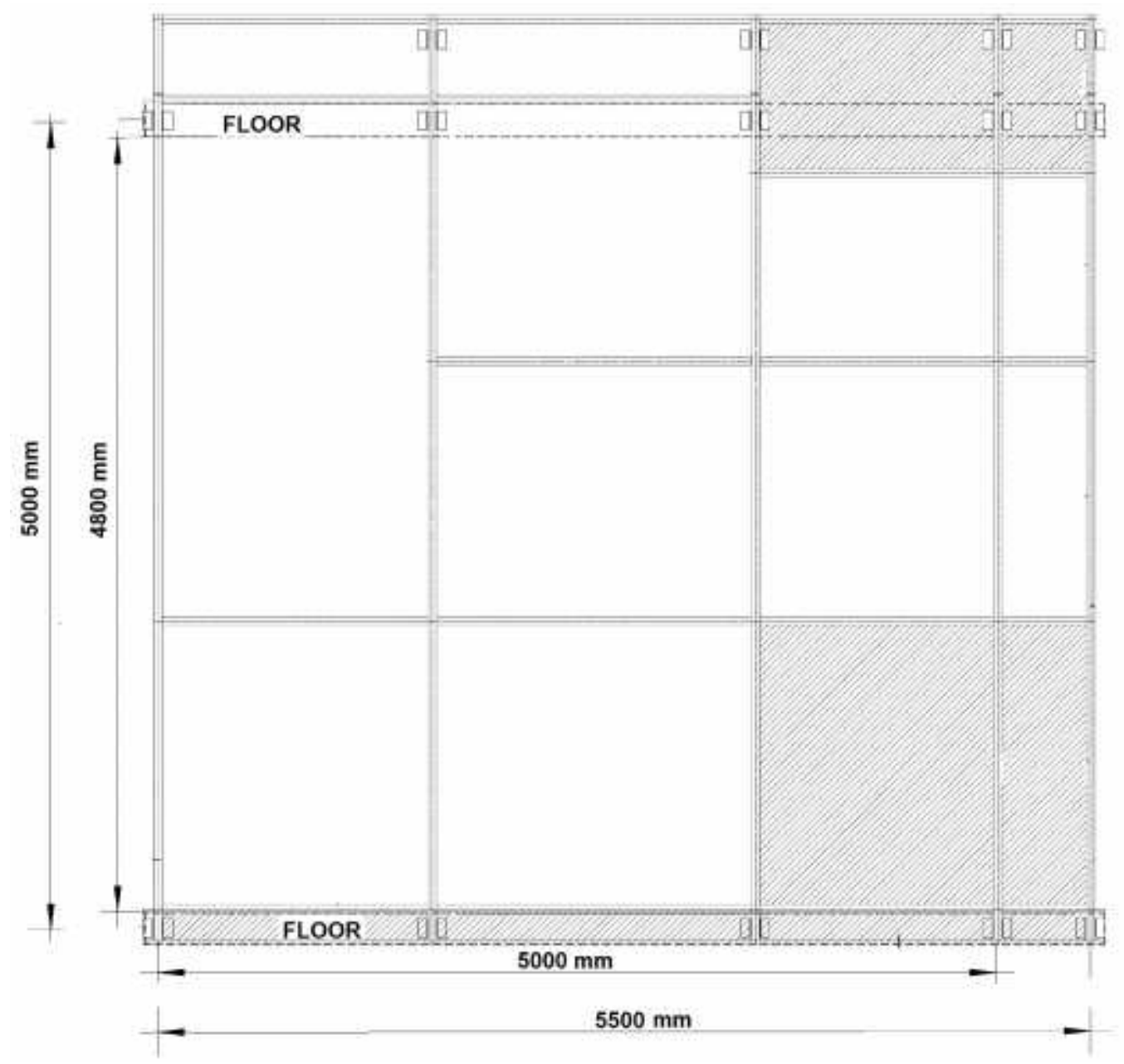

Fig. 3 General view of tested specimen (internal fire exposure)

Two types of insulation inserts were used in profiles, each type for pair of tests (external and internal fire exposure). Two types of glass panes were used in test specimens, each type for pair of tests (external and internal fire exposure). Glass panes were of symmetrical structure. The comparison of average temperature rises on the profiles and glass panes are presented in the latest articles (Sedtak et al., 2013). This paper presents the comparison of deflection during the tests and average temperature rises separately for each mullion in the heated area.

The temperature measurements for average temperature rise were measured in the same height of the middle mullions - for external fire exposure thermocouples were placed on the aluminium profile and for the internal fire exposure thermocouples were placed on the aluminium masking strip. The deflection of the test specimen was measured in the middle height of the mullions.

Figure 4 presents comparison of average temperature rises on the mullions filled by means of special cooling plates.

Figure 5 presents comparison of average temperature rises on the mullions filled by means of plasterboards with cellulose fibers.

Table 2 presents the deflection of each mullion during the test. 


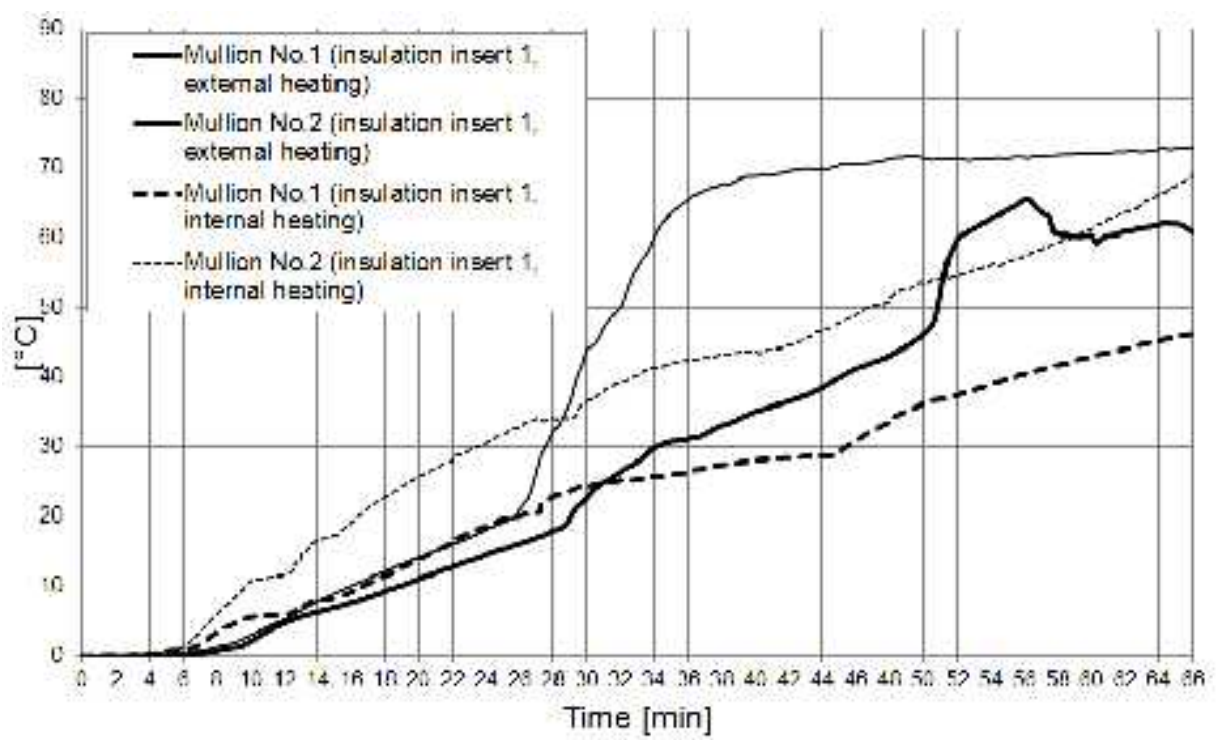

Fig. 4 Comparison of average temperature rises on the mullions filled with insulation insert No. 1 (Mullion No. 1 - second from the left side in fig. 3, Mullion No. 2 - third from the left in fig. 2)

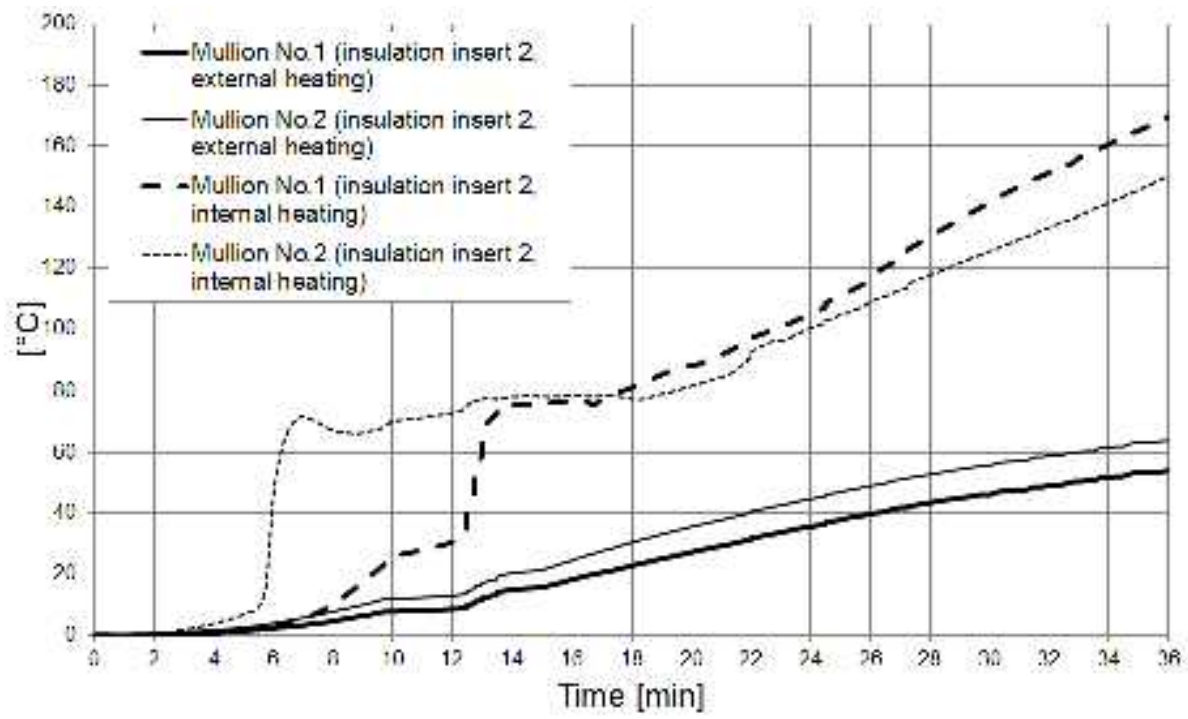

Fig. 5 Comparison of average temperature rises on the mullions filled with insulation insert No. 2 (Mullion No. 1 - second from the left side in fig. 3, Mullion No. 2 -third from the left in fig. 2)

Table 2 Mullions deflection in mm ("“+” towards and "“-" outside the furnace)

\begin{tabular}{|c|c|c|c|c|c|c|c|c|}
\hline \multirow{2}{*}{$\begin{array}{c}\text { Time } \\
{\left[\begin{array}{c}\text { [min] } \\
\end{array}\right.}\end{array}$} & \multicolumn{4}{|c|}{ External heating } & \multicolumn{4}{c|}{ Internal heating } \\
\cline { 2 - 9 } & Insulation insert 1 & Insulation insert 2 & \multicolumn{2}{c|}{ Insulation insert 1 } & Insulation insert 2 \\
\cline { 2 - 9 } & Mullion 1 & Mullion 2 & Mullion 1 & Mullion 2 & Mullion 1 & Mullion 2 & Mullion 1 & Mullion 2 \\
\hline 0 & 0 & 0 & 0 & 0 & 0 & 0 & 0 & 0 \\
\hline 10 & 2 & 5 & 16 & 17 & -9 & -7 & -1 & 3 \\
\hline 20 & 2 & 5 & 18 & 19 & -38 & -32 & -17 & -17 \\
\hline 25 & 3 & 7 & 18 & 19 & -42 & -33 & -20 & -19 \\
\hline 30 & 4 & 10 & 18 & 20 & -45 & -35 & -24 & -22 \\
\hline 40 & 4 & 10 & 18 & 20 & -52 & -40 & - & - \\
\hline 50 & 5 & 10 & 17 & 20 & -32 & -68 & - & - \\
\hline 55 & 5 & 10 & 17 & 20 & -29 & -83 & - & - \\
\hline 60 & 5 & 8 & 17 & 19 & -39 & -93 & - & - \\
\hline
\end{tabular}


Fire resistance of large aluminium glazed curtain walls depends on many factors of the system solution such as: type of glazing, glazing fixing, profile material and shape, type of insulation inserts used. Analysing graphs presented in Fig. 4 and 5 it can be observed, that the side of fire exposure can have an major influence on the temperature rises on the surface of the curtain wall profiles and also the deflection of the test specimen. Arguably the most interesting fact is that, in case of the heating under the external temperature-time curve despite the lower temperature in the furnace and lower deflection module the temperature rises on the aluminium profiles aren't always lower in comparison to results recorded in test performed under the standard (internal) temperaturetime curve. Described phenomenon confirms the necessity of verifying the fire resistance of curtain walls from both sides.

\section{REFERENCES}

Kinowski J., 2015. Bezpieczeństwo po arowe przeszklonych ścian ostonowych (kurtynowych). Świat Szkła, 20(5), p. 8-14.

Kinowski J., Sędłak B., Sulik P., 2015. Izolacyjność ogniowa aluminiowo - szklanych ścian ostonowych w zale ności od sposobu wypetnienia profili szkieletu konstrukcyjnego. Izolacje, 20(2), p. 48-53.

Kinowski J., Sulik P., 2014. Bezpieczeństwo u ytkowania elewacji. Materiaty Budowlane, 9, p. 38-39.

Roszkowski P., Sędłak B., 2011. Metodyka badań odporności ogniowej dachów przeszklonych. Świat Szkła, 16(6), p. 50-52.

Roszkowski P., Sędłak B., 2014. Badania odporności ogniowej poziomych elementów przeszklonych. Świat Szkła, 19(12).

Sędłak B., 2012. Badania odporności ogniowej przeszklonych ścian ostonowych - Czesść 1. Świat Szkła, 17(9), p. 52-54.

Sędłak B., 2012. Badania odporności ogniowej przeszklonych ścian ostonowych - Czesść 2. Świat Szkła, $17(10)$, p. 53-58,60.

Sędłak B., 2013. Systemy przegród aluminiowo szklanych o określonej klasie odporności ogniowej. Świat Szkta, 18(10), p. 30-33,41.

Sędłak B., 2014. Badania odporności ogniowej przeszklonych ścian ostonowych wg nowego wydania normy PN-EN 1364-3. Świat Szkła, 19(7-8), p. 49-53.

Sędłak B., 2014. Odporność ogniowa ścian ostonowych z du ymi przeszkleniami - Część 1. Świat Szkła, 19(3), p. 16-19,25.

Sędłak B., 2014. Odporność ogniowa ścian ostonowych z du ymi przeszkleniami - Część 2. Świat Szkła, 19(5), p. 28-31.

Sędłak B., Kinowski J., 2013. Badania odporności ogniowej ścian ostonowych - przyrosty temperatury na szybach. Świat Szkła, 18(11), p. 20-25.

Sędłak B., Kinowski J., Borowy A., 2013. Fire resistance tests of large glazed aluminium curtain wall test specimens-results comparison. MATEC Web of Conferences, 9, p. 02009, EDP Sciences, DOI: 10.1051/matecconf/20130902009.

Sulik P., Sędłak B., Kinowski J., 2014. Bezpieczeństwo po arowe ścian zewnętrznych - Część 1 - Elewacje szklane: wymagania, badania, przyktady. Ochrona przeciwpo arowa, 4(50), p. 10-16.

Sulik P., Sędłak B., Kinowski J., 2015. Bezpieczeństwo po arowe ścian zewnętrznych - Cześć 2 Mocowanie okładzin elewacyjnych. Ochrona przeciwpo arowa, 1(51), 9-12.

Sulik P., Sędłak B., Turkowski P., Węgrzyński W., 2014. Bezpieczeństwo po arowe budynków wysokich i wysokościowych, in Budownictwo na obszarach zurbanizowanych - nauka, praktyka, perspektywy, 14-19 September 2014, Krynica, Poland, p. 105-120. 